Zeszyty Naukowe Szkoły Głównej Gospodarstwa Wiejskiego w Warszawie

Problemy Rolnictwa Światowego tom 18 (XXXIII), zeszyt 1, 2018: 235-247

DOI: $10.22630 /$ PRS.2018.18.1.22

Stanisław Stańko, ${ }^{1}$ Aneta Mikuła ${ }^{2}$

Szkoła Główna Gospodarstwa Wiejskiego w Warszawie

\title{
Tendencje na rynku mleka na świecie i w Polsce w latach 2000-2016
}

\section{Tendencies in the World Milk Market and in Poland in the Years 2000-2016}

\begin{abstract}
Synopsis. Opracowanie przedstawia zmiany w produkcji mleka na świecie w latach 2000-2016. Przedstawiono zmiany ogółem oraz u największych producentów. W badanych latach produkcja mleka ogółem zwiększała się przeciętnie w roku o 15 mln ton, tj. w tempie 2,18\%. W 2016 r. udział mleka krowiego w produkcji wynosił $82,6 \%$, bawolego $13,9 \%$, a mleka koziego, owczego i wielbłądziego wynosił $3,4 \%$. Zmiany produkcji u największych producentów mleka były zróżnicowane co do kierunków i skali. Zróżnicowane były również kierunki zmian zużycia krajowego mleka. Na tej podstawie wyodrębniono trzy grupy krajów: o rosnących nadwyżkach rynkowych, o rosnących niedoborach rynkowych i o spadających nadwyżkach rynkowych mleka. W największej skali rosły nadwyżki rynkowe mleka w USA, Nowej Zelandii i krajach UE. Z tych krajów w $2016 \mathrm{r}$. pochodziło prawie $80 \%$ światowego eksportu mleka i jego produktów. W mniejszej skali nadwyżki rynkowe zwiększały się także w Argentynie i Turcji. Rosnące niedobory rynkowe mleka i jego produktów w największej skali występowały w Chinach i Rosji, a także w mniejszej skali w Meksyku, Brazylii i Pakistanie. Tendencja spadkowa w nadwyżkach rynkowych występowała w Australii, Ukrainie a także w Indiach. Polska charakteryzowała się rosnącymi nadwyżkami rynkowymi mleka i jego produktów, co powodowało wzrost eksportu. Na rynkach zagranicznych niezbędne było zagospodarowanie 2/3 przyrostu produkcji mleka w Polsce.
\end{abstract}

Słowa kluczowe: mleko, produkcja, zużycie krajowe, nadwyżki rynkowe

\begin{abstract}
The study presents changes in milk production in the world in 2000-2016. Production changes in general as well as in the largest producers were presented. In the analysed years, total milk production increased on average by 15 million tons per year, i.e. at the rate of $2.18 \%$. In 2016, the share of cow's milk in production was $82.6 \%$, buffalo $13.9 \%$, and goat's, sheep's and camel's milk was $3.4 \%$. Production changes in the largest milk producers varied in directions and scale. Similarly, the directions of changes in the consumption of domestic milk also varied. On this basis, three groups of countries were distinguished: growing market surpluses, growing market shortages and falling market surpluses of milk. The market surpluses of milk in the USA, New Zealand and EU countries grew on the largest scale. In 2016, almost $80 \%$ of global exports of milk and its products came from these countries. On a smaller scale, market surpluses also increased in Argentina and Turkey. The growing market shortages of milk and its products in the largest scale occurred in China and Russia, and on a smaller scale in Mexico, Brazil and Pakistan. The downward trend in market surpluses occurred in Australia, Ukraine and in India. In Poland there were growing market surpluses of milk and its products, which resulted in an increase in exports. It was necessary to develop $2 / 3$ of Polish milk production growth in foreign markets.
\end{abstract}

Key words: milk, production, domestic consumption, market surpluses

JEL Classification: Q110, Q130, Q170

${ }^{1}$ prof. dr hab., Katedra Ekonomiki Rolnictwa i Międzynarodowych Stosunków Gospodarczych SGGW, ul. Nowoursynowska 166,02-787 Warszawa, e-mail: stanisław_stanko@sggw.pl; https://orcid.org/0000-0001-9698-9316

${ }^{2}$ dr inż., Katedra Ekonomii i Polityki Gospodarczej SGGW, ul. Nowoursynowska 166, 02-787 Warszawa, e-mail: aneta_mikula@sggw.pl; https://orcid.org/0000-0001-7129-6898 


\section{Wstęp}

Produkcja mleka w Polsce i w wielu innych krajach jest ważną gałęzią produkcji rolniczej. Wynika to $\mathrm{z}$ udziału tej produkcji w kształtowaniu przychodów ze sprzedaży produkcji rolniczej, znaczącego udziału w obrotach handlu zagranicznego produktami rolno-spożywczymi, jak też z wielkości wydatków gospodarstw domowych na mleko i jego przetwory. W $2016 \mathrm{r}$. udział skupu mleka w wartości skupu produktów rolnych w Polsce wynosił 20,5\% (Rolnictwo..., 2017, s. 115), w 2000 r. było to 23,0\% (Rolnictwo..., 2004, s. 102). W handlu zagranicznym produktami rolno-spożywczymi udział mleka i jego przetworów wynosił w eksporcie w 2000 r. - 8,9\%, a w 2016 r. - 6,8\%, a w imporcie odpowiednio: $2,9 \%$ i $4,7 \%$. Dodatnie saldo handlu zagranicznego tą grupą produktów wynosiło w 2000 r. 154,7 mln EUR ${ }^{3}$, i zwiększyło się w 2016 r. do 691,7 mln EUR (Handel zagraniczny..., 2001, s. 37, i 2017, s. 46). Wzrost dodatniego salda handlu zagranicznego wyrobami mleczarskimi w badanych latach wyniósł $347,1 \%$.

Znaczenie handlu zagranicznego w kształtowaniu koniunktury na rynku mleka w Polsce jest bardzo ważne. Wynika to z konieczności zagospodarowania na rynkach zagranicznych znacznych nadwyżek produkcji w kraju. Nadwyżki te systematycznie zwiększają się. W 2000 r. eksport produktów mleczarskich w ekwiwalencie mleka wyniósł $890 \mathrm{mln}$ ton, co stanowiło 7,5\% produkcji ${ }^{4}$, a w 2016 r. eksport mleka i jego przetworów wyniósł 3,88 mln ton mleka ${ }^{5}$, co stanowiło 29,2\% produkcji (Rynek mleka ..., nr 53, s. 3).

Rosnące powiązanie krajowego rynku mleka z rynkami zagranicznymi poprzez obroty handlowe jest jednym z głównych czynników wpływających na koniunkturę i produkcję w Polsce. „Kierunki zmian skupu mleka i cen zbytu jego przetworów w Polsce charakteryzowały się analogicznymi kierunkami zmian jak ceny światowe produktów mleczarskich" (Szajner, 2017, s. 19). Oznacza to, że rynek krajowy jest skointegrowany z rynkiem światowym. Stwarza to konieczność oceny prawidłowości występujących na rynkach zagranicznych, które decydują o sytuacji na rynku i możliwościach rozwoju produkcji w kraju.

\section{Cel opracowania, materiał, metody analizy}

Celem opracowania było określenie dominujących kierunków zmian w kształtowaniu się produkcji i zużycia krajowego na rynku mleka i jego produktów, u głównych jego producentów na świecie. Do głównych producentów mleka zaliczono te kraje, które w ostatnich 5 latach (2012-2016) wytwarzały co najmniej 9 mln ton rocznie. Były to: kraje Unii Europejskiej, USA, Indie, Chiny, Pakistan, Rosja, Brazylia, Nowa Zelandia, Turcja, Meksyk, Ukraina, Argentyna i Australia. Udział tych krajów w światowej produkcji mleka krowiego w 2016 r. wynosił 81,6\% $\%^{6}$, a w 2000 r. - 80,7\%. Przedmiotem analizy była produkcja mleka, jego zużycie i nadwyżki rynkowe ponad potrzeby krajowe w latach 2000-2016.

\footnotetext{
${ }^{3}$ Oszacowano saldo w EUR na podstawie danych wyrażonych w USD i kursu EUR/USD.

${ }^{4}$ Oszacowano na podstawie Handel zagraniczny...nr 16, s. 31.

${ }^{5}$ Wolumen eksportu mleka IERiGŻ-PIB liczy wykorzystując wskaźniki zawartości suchej masy w produktach mleczarskich.

${ }^{6}$ Obliczono na podstawie danych FAOSTAT (www.fao.org/faostat/en/\#data), Explore Data Production Livestock Primary.
} 
Podstawowym źródłem informacji byłe dane Faostatu i Eurostatu. Siedemnastoletni okres pozwolił wyodrębnić dominujące kierunki zmian, które określono na podstawie modeli tendencji, a do pomiaru dynamiki badanych kategorii (produkcji, zużycia krajowego nadwyżek rynkowych) wykorzystano indeksy statystyczne (Jóźwiak i Pogórski, 1998) oraz tempo (stopę) zmian, przy obliczaniu którego uwzględniono wszystkie wyrazy szeregu chronologicznego (Timofiejuk, 1990).

\section{Tendencje w produkcji mleka}

W żywieniu człowieka i przemyśle rolno-spożywczym wykorzystywane są różne rodzaje mleka. Są to mleko krowie, bawole, kozie, owcze, wielbłądzie oraz w niektórych obszarach mleko kobyle (np. w Mongolii), mleko reniferów (np. w Laponii), jaków (np. w Tybecie), lamy (np. w Peru). Znaczenie i rola gatunków zwierząt do produkcji mleka jest zróżnicowana w poszczególnych regionach i państwach świata. Podstawowe znaczenie w tym zakresie ma dostęp do określonego rodzaju paszy, zasoby wody i warunki klimatyczne (Faye i Konuspayeva, 2012). Duże znaczenie mają także popyt rynkowy na mleko, zwyczaje żywieniowe i cechy społeczno-ekonomiczne gospodarstw domowych (Guliński i Salamończyk, 2016, s. 120).

W produkcji na świecie dominuje mleko krowie. Stanowi ono 82-84\% produkcji mleka ogółem. Znacząca jest także produkcja mleka bawolego, które stanowi 12-13\% produkcji mleka ogółem. Najwięcej mleka bawolego produkuje się w Indiach, Pakistanie i Chinach, a w Europie we Włoszech. W produkcji dominuje mleko krowie i bawole, które stanowią około $96 \%$ produkcji mleka ogółem ${ }^{7}$.

Kierunki zmian w produkcji mleka na świecie przedstawiono na rys. 1.

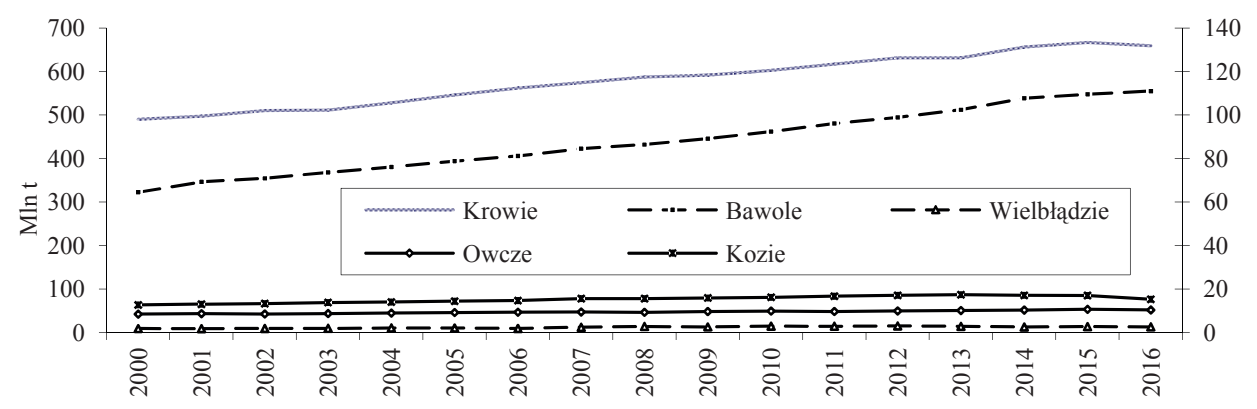

Rys. 1. Produkcja różnych rodzajów mleka na świecie w latach 2000-2016 (mln t, prawa i lewa oś)

Fig. 1. Production of various types of milk in the world in 2000-2016 (million tonnes)

Źródło: opracowanie własne na podstawie FAOSTAT(www.fao.org/faostat/en/\#data).

W latach 2000-2016 produkcja mleka surowego na świecie charakteryzowała się tendencją wzrostową, która wynosiła przeciętnie $\mathrm{w}$ roku $15,0 \mathrm{mln}$ ton, a roczne tempo wzrostu wynosiło $2,18 \%$. W przyroście tym dominowało mleko krowie, którego produkcja rosła rocznie o $11,62 \mathrm{mln}$ ton, tj. w tempie 2,02\%. Szybszym tempem wzrostu

${ }^{7}$ Obliczono na podstawie danych FAOSTAT (www.fao.org/faostat/en/\#data). 
charakteryzowała się produkcja mleka bawolego, którego produkcja rosła średnio $\mathrm{w}$ roku o 2,91 mln ton t, tj. w tempie 3,35\%. W wyniku tego udział mleka bawolego w produkcji ogółem zwiększył się z 11,1\% w 2000 r. do 13,9\% w 2016 r., a mleka krowiego zmniejszył się odpowiednio z $84,7 \%$ do $82,6 \%$. Tendencją wzrostową charakteryzowała się także produkcja mleka wielbłądziego. Jego produkcja wzrastała przeciętnie w roku o $0,07 \mathrm{mln}$ ton, tj. 3,21\%, owczego odpowiednio: $0,13 \mathrm{mln}$ ton i 1,38\%, koziego $-0,27 \mathrm{mln}$ ton $\mathrm{i}$ $1,83 \%$. Udział w produkcji ogółem mleka wielbłądziego, owczego i koziego był niewielki i wynosił 4,4\% w 2000 r. i zmniejszył się do 3,4\% w 2016 r. Tendencje w produkcji mleka u największych i dużych światowych jego producentów przedstawiono na rys. 2 i 3.

W grupie dużych światowych producentów mleka można wyodrębnić dwie podgrupy: największych, produkujących ponad $90 \mathrm{mln}$ ton mleka rocznie i dużych, produkujących więcej niż $9 \mathrm{mln}$ ton, ale mniej niż $90 \mathrm{mln}$ ton.

Do największych światowych producentów mleka można zaliczyć: kraje UE, Indie i USA. Dla tych krajów tendencje w produkcji i zużyciu krajowym przedstawiono na rys. 2.

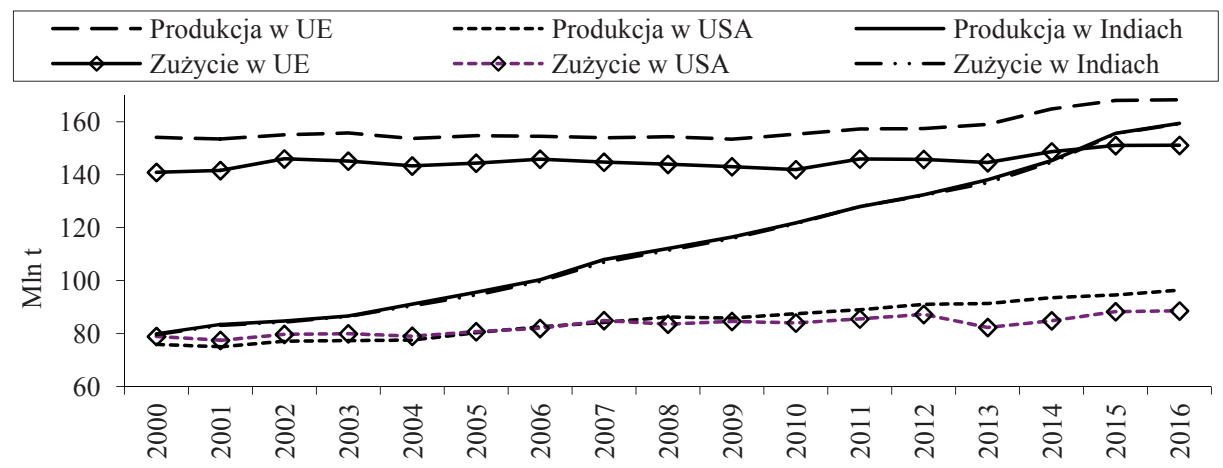

Rys. 2. Produkcja i zużycie krajowe największych producentów mleka na świecie w latach 2000-2016 (mln t)

Fig 2. Production and domestic consumption of the largest milk producers in the world in 2000-2016 (million tonnes)

Źródło: opracowanie na podstawie FAOSTAT (2017) (www.fao.org/faostat/en/\#data) i FAO Food,... 2015, 2016, 2017.

W krajach UE od wielu lat produkuje się najwięcej mleka na świecie. Do największych producentów mleka w UE zalicza się następujące kraje: Niemcy, które w 2016 r. wyprodukowały 32,7 mln t, Francję (26,1 mln t.), Wielką Brytanię (14,9 mln t), Holandię (14,3 mln t), Polskę (13,3 mln t) i Włochy (12,7 mln t) (Eurostat 2017). Ogółem w produkcji mleka w krajach UE dominowało mleko krowie, którego produkcja w $2016 \mathrm{r}$. wyniosła $163 \mathrm{mln} \mathrm{t}$, a jego udział w produkcji mleka ogółem wyniósł 96,8\%. Oprócz mleka krowiego kraje UE produkowały także mleko owcze - 2,8 mln t, tj. 1,7\% produkcji ogółem, kozie - 2,3 mln t (1,3\% produkcji) i mleko bawole - 0,3 mln t $(0,2 \%$ produkcji) (Eurostat 2017). W kształtowaniu produkcji mleka w krajach UE można wyróżnić dwa okresy: pierwszy, w którym obowiązywały kwoty mleczne i ulegały niewielkim zmianom i lata, w których stopniowo zwiększano kwoty produkcji, a następnie je zlikwidowano. Kwoty mleczne wprowadzono w 1984 r. w celu ograniczenia nadprodukcji mleka (Integracja ..., 2002, s. 51). Kwoty mleczne były to określone ilościowo rozmiary sprzedaży mleka do mleczarni (tzw. kwota hurtowa), jak i sprzedaży bezpośredniej przez 
producentów konsumentom. Przekroczenie kwoty przez państwo członkowskie w roku kwotowym (od 1 kwietnia do 31 marca) skutkowało nakładanymi bezpośrednio na producentów opłatami. Wprowadzenie kwot było znaczącym czynnikiem kształtującym podaż, popyt i ceny poprzez ograniczenie podaży mleka. Ograniczenia kwotowe powodowały uzyskiwanie wyższych cen za mleko posiadaczom kwot. Kwoty ograniczały wzrost produkcji, hamowały procesy restrukturyzacji, oraz zakłócały reakcje rolników na sygnały płynące z rynku. W tej sytuacji w 2008 r. w ramach tzw. Healt Check Komisja Europejska podjęła decyzję o zniesieniu kwot produkcji mleka od 1 kwietnia 2015 r. W celu odpowiedniego dostosowania się producentów mleka do nowej sytuacji podjęto decyzję o stopniowym zwiększaniu kwot produkcji o 1\% począwszy od roku kwotowego 2009/2010 (Rozp. Rady (WE) Nr 72/2009). Przedstawione uwarunkowania powodowały, że produkcja mleka ogółem w UE w latach 2000-2009 charakteryzowała się nieznaczną tendencją spadkowa, przeciętnie $\mathrm{w}$ roku o $0,05 \mathrm{mln}$. Jednak dostawy mleka do przetwórców zwiększały się poprzez wzrost towarowości produkcji. Od 2010 r. produkcja mleka w krajach UE zwiększała się przeciętnie w roku o 2,429 mln t, tj. o 1,5\% rocznie. Takie kierunki zmian oznaczały, przyśpieszenie wzrostu produkcji w UE po likwidacji kwot mlecznych.

Drugim największym światowym producentem mleka są Indie. W badanych latach produkcja mleka ogółem zwiększała się przeciętnie w roku o 5,064 mln t, tj. w tempie $4,45 \%$. W produkcji dominowało mleko bawole i krowie. Dynamiczny wzrost produkcji dotyczył zarówno mleka krowiego, jak i bawolego. W latach 2000-2016 wzrost produkcji mleka bawolego wyniósł 79,7\%, a krowiego 134,5\%. W wyniku różnej dynamiki wzrostu w produkcji ogółem zwiększył się udział mleka krowiego z 41,3\% w 2000 r. do 48,6\% w 2016 r, a zmniejszył udział mleka bawolego z 54,4\% w 2000 r. do 48,9\% w 2015 r. Udział tych dwóch rodzajów mleka w produkcji ogółem wynosił w 2000 r. 95,7\% i zwiększył się do $97,5 \%$ w 2016 r. Takie zmiany oznaczały zmniejszenie w produkcji udziału mleka koziego z 4,1\% w 2000 r. do 2,4\% w 2016 r., a mleka owczego odpowiednio: z $0,2 \%$ do $0,1 \%$. To zmniejszenie udziału wynikało z niskiej dynamiki wzrostu produkcji. W latach 2000-2016 produkcja mleka koziego zwiększyła się o 15,4\%, a owczego o 4,6\%. Duża dynamika wzrostu produkcji mleka w Indiach spowodowała zwiększenie udziału tego kraju w światowej produkcji z 13,8\% w 2000 r. do 20\% w 2016 r.

W USA w produkcji dominowało mleko krowie. Nieznaczna była produkcja mleka koziego, którego udział w produkcji wynosił $0,03 \%$. W badanych latach produkcja mleka krowiego zwiększała się przeciętnie w roku o $1,376 \mathrm{mln} \mathrm{t}$ ( $\mathrm{w}$ tempie $1,62 \%$ ), a udział USA w produkcji mleka na świecie w latach 2000-2016 zmniejszył się z 13,1\% do $12,1 \%$.

Kraje UE, Indie i USA produkowały w 2000 r. 53,7\% światowej produkcji mleka i udział ten nieznacznie się zmniejszył do 53,1\% w $2016 \mathrm{r}$.

Tendencje $\mathrm{w}$ produkcji mleka $\mathrm{u}$ dużych jego producentów były zróżnicowane w kierunkach i skali zmian, co przedstawiono na rys. 3 .

W krajach dużych producentów mleka wysokie tempo wzrostu produkcji (wyższe od tempa światowego) występowało w: Chinach, Brazylii, Nowej Zelandii, Turcji i Pakistanie. Natomiast tempo wzrostu produkcji mleka w takich krajach, jak: Meksyk i Argentyna było niższe niż na świecie. Tendencja spadkowa w produkcji występowała w takich krajach, jak Rosja, Ukraina i Australia.

W latach 2000-2016 produkcja mleka w Chinach charakteryzowała się tendencją wzrostową. W badanych latach produkcja mleka ogółem zwiększyła się 3,4-krotnie. Najwyższą dynamiką charakteryzowała się produkcja mleka krowiego, którego produkcja 
wzrosła 4,3-krotnie. Niższą dynamiką charakteryzowała się produkcja mleka bawolego (wzrost o 17\%), koziego (wzrost o 17\%), owczego (wzrost o 60,5\%). W wyniku różnej dynamiki nastąpiły zmiany $\mathrm{w}$ strukturze produkcji. Zwiększył się $\mathrm{w}$ produkcji ogółem udział mleka krowiego z 69,4\% w 2000 r. do 88,4\% w 2016 r., a zmniejszył mleka bawolego z 21,4\% w 2000 r. do 7,4\% w 2016 r. Zmniejszył się także udział w produkcji pozostałych rodzajów mleka (owczego, koziego i wielbłądziego) z 9,2\% w 2000 r. do 4,2\% w 2016 r. W produkcji mleka ogółem w Chinach można wydzielić dwa okresy: szybkiego wzrostu (lata 2000-2007) i powolnego wzrostu (2008-2016). W latach szybkiego wzrostu, produkcja mleka ogółem zwiększała się rocznie o 4,164 mln t, tj. w tempie 17,3\%, natomiast spowolnienie wzrostu wystapiło w latach 2008-2016. W tym okresie produkcja rosła rocznie o $0,245 \mathrm{mln} \mathrm{t}$, $\mathrm{tj}$. $\mathrm{w}$ tempie $0,6 \%$ rocznie.

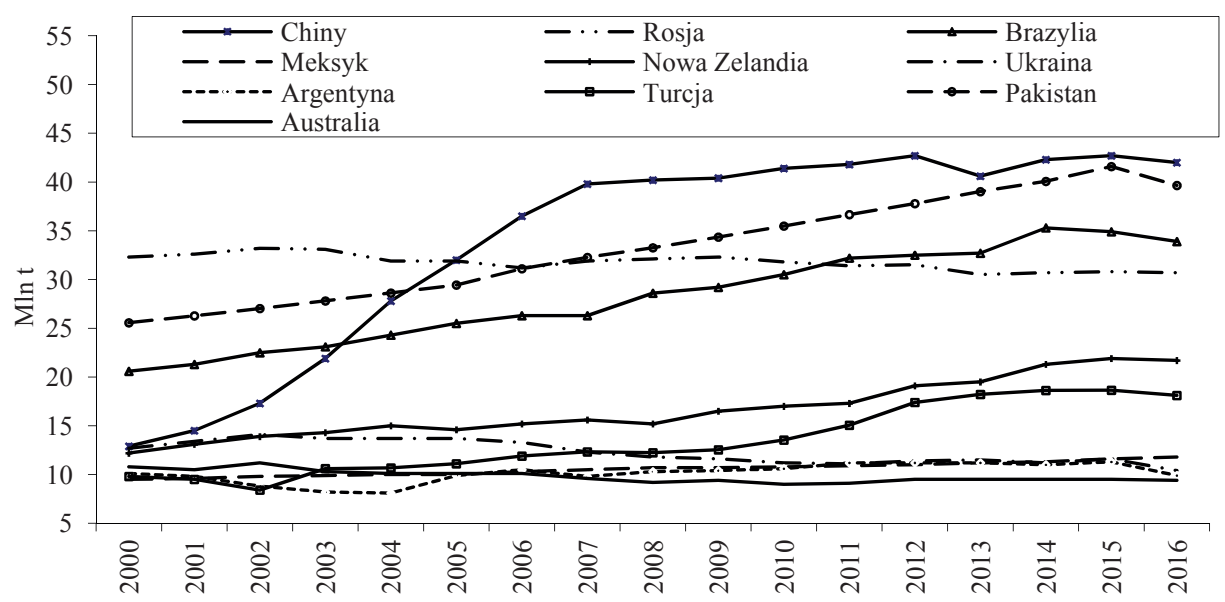

Rys. 3. Produkcja mleka dużych światowych producentów w latach 2000-2016 (mln t)

Fig. 3. Milk production of large global producers in 2000-2016 (million tonnes)

Źródło: opracowanie własne na podstawie FAOSTAT (2017) i FAO Food..., 2015, 2016, 2017).

W Brazylii w produkcji dominowało mleko krowie. Jego udział w produkcji wynosił $98,7 \%$ w 2000 r. i 99,3\% w 2016 r. Pozostałe to mleko kozie. Produkcja mleka w Brazylii zwiększała się rocznie o $0,957 \mathrm{mln} \mathrm{t}$, tj. w tempie $3,47 \%$. Dynamika wzrostu produkcji była wyższa niż produkcji mleka ogółem na świecie. Podobną dynamiką charakteryzowała się produkcja mleka w Nowej Zelandii. Roczna stopa wzrostu wynosiła 3,45\%, a przyrost bezwzględny wynosił $0,581 \mathrm{mln}$ t. dla mleka krowiego.

Wysoką dynamiką wzrostu charakteryzowała się produkcja mleka ogółem w Turcji. Przeciętnie w roku wzrost produkcji wynosił $0,666 \mathrm{mln} \mathrm{t}$, tj. w tempie $4,95 \%$. Produkcja mleka krowiego zwiększyła się o $92,3 \%$, niższą dynamiką cechowała się produkcja mleka owczego (20\%), koziego (56,4\%), a także bawolego (spadek o 61,1\%). Takie kierunki zmian spowodowały zmiany struktury produkcji mleka. Zwiększył się udział w produkcji mleka krowiego z 89,2\% w 2000 r. do $92,7 \%$ w 2016 r., a zmniejszył mleka owczego z $7,9 \%$ w 2000 r. do $5,1 \%$ w 2016 r., oraz odpowiednio: mleka koziego z $2,2 \%$ do $1,9 \%$, i bawolego z $0,7 \%$ do $0,3 \%$. W Pakistanie produkcja mleka ogółem zwiększała się przeciętnie w roku o $1,037 \mathrm{mln} \mathrm{t}$, tj. w tempie 3,59\%.W największej skali zwiększyła się produkcja mleka krowiego (o 68,5\%), i bawolego (o 51,7\%). Niższa skala wzrostu 
charakteryzowała produkcję mleka koziego i owczego. W wyniku takich zmian w strukturze produkcji zwiększył się udział mleka krowiego (z 31,5\% w 2000 r. do 33,1\% w 2016 r.), a zmniejszył bawolego (z 66,1\% w 2000 r. do 64,7\% w 2016 r.), a także koziego i owczego (z 2,4\% w 2000 r. do 2,2\% w 2016 r.).

W Meksyku dominowało mleko krowie, którego udział w produkcji wynosił 98,2\%. $\mathrm{W}$ badanych latach roczny wzrost produkcji wynosił $0,138 \mathrm{mln} \mathrm{t}, \mathrm{tj} .1,3 \%$. Podobna skala i tempo wzrostu produkcji mleka występowały w Argentynie (0,133 mln t i 1,34\%).

W Rosji produkcja mleka w latach 2000-2016 charakteryzowała się tendencja spadkowa, przeciętnie w roku o $0,142 \mathrm{mln} \mathrm{t}, \mathrm{tj}$. w tempie $0,42 \%$, w Australii odpowiednio: 0,098 mln t, tj. w tempie $1 \%$, i Ukrainie $0,201 \mathrm{mln} \mathrm{t}, \mathrm{tj}$. w tempie $1,63 \%$. W tych trzech krajach w produkcji dominowało mleko krowie (97,6\% i więcej).

\section{Tendencje w zużyciu krajowym mleka}

Wytworzone mleko stanowi surowiec, który podlega rozdysponowaniu. Część mleka jest spasana w gospodarstwach rolnych oraz spożyta w gospodarstwach domowych (tzw. samozaopatrzenie), a dominującą część stanowi sprzedaż podmiotom przetwórczym, gdzie wytwarzane są różne produkty mleczarskie. W warunkach gospodarki rynkowej dominuje sprzedaż mleka do przemysłu przetwórczego (mleczarni). Relację sprzedaży do produkcji mleka określa się jako towarowość produkcji. Towarowość produkcji mleka zmienia się wraz z rozwojem społeczno-gospodarczym. W krajach o wyższym poziomie rozwoju w gospodarstwie zużyta zostaje niewielka część wytworzonego mleka. Na przykład w 2016 r. towarowość produkcji mleka krowiego wynosiła w Danii 98,7\%, Wielkiej Brytanii 98,3\%, Niemczech 97,8\%, Francji 93,9\%, Bułgarii 45,6\%, Rumunii 20,8\%, a w Polsce 84, $1 \%{ }^{8}$.

Przy ocenie zużycia mleka w kraju należy uwzględnić nie tylko produkcję, ale także obroty handlu zagranicznego. Czasami dysponując szczegółowymi danymi uwzględnia się także różnice wielkości zapasów, straty poniesione w trakcie procesów produkcyjnych i przechowywania9 ${ }^{9}$ Zużycie oblicza się uwzględniając produkcję krajową pomniejszoną o eksport i powiększoną o import przetworów mlecznych przeliczonych na ekwiwalent mleka surowego.

Kierunki zmian w zużyciu krajowym ${ }^{10}$ największych światowych producentów mleka przedstawiono na rysunku 2, a u dużych jego producentów na rys. 4.

Zużycie mleka w krajach UE w latach 2000-2016 zwiększało się przeciętnie w roku o 0,406 mln t, tj. w tempie $0,28 \%$. Taka skala i tempo zmian oznaczają, że wzrost zużycia wewnętrznego był mniejszy niż przyrost produkcji o $0,363 \mathrm{mln}$ t. Dotyczy to całego badanego okresu. Znaczne przyśpieszenie wzrostu produkcji nastapiło w latach 2010-2016. W tym okresie przyrost produkcji był o $0,977 \mathrm{mln}$ ton większy niż przyrost zużycia.

\footnotetext{
${ }^{8}$ Obliczenia własne na podstawie danych Eurostat (2017): Production and utylization of milk on the farm oraz milk collection and dairy product obtained.

${ }^{9}$ Ze względu na brak danych szczegółowych w statystyce często sporządza się bilanse uwzględniające produkcję i saldo handlu zagranicznego przetworami wyrażonymi w ekwiwalencie mleka surowego (Seremak-Bulge, 2017, s. 46). Dane FAO były podstawą do oceny tendencji w produkcji i zużyciu krajowym.

${ }^{10}$ Kategorię ,zużycie krajowe” mleka otrzymano odejmując od produkcji eksport i dodając import. W tej kategorii dominuje zużycie konsumpcyjne mleka, zużycie paszowe jak i inne.
} 
Oznaczało to powstawanie nadwyżek produkcji mleka, których zagospodarowanie na rynkach krajów trzecich ${ }^{11}$ było niezbędne.

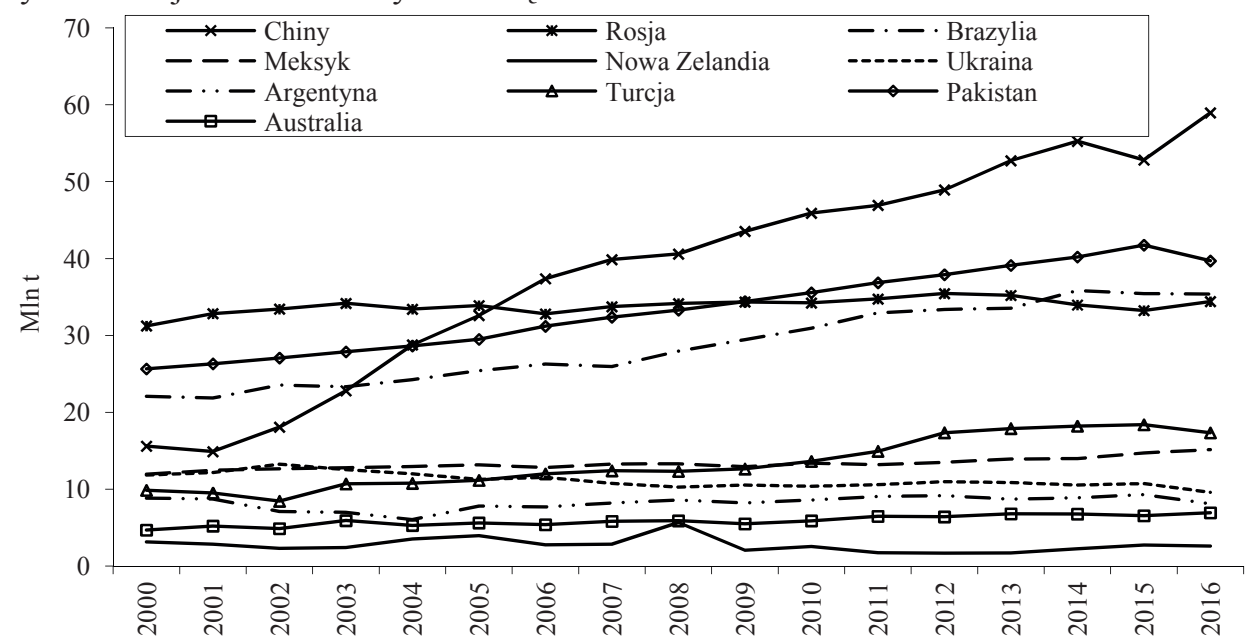

Rys. 4. Zużycie krajowe mleka dużych światowych producentów w latach 2000-2016 (mln t)

Fig. 4. Domestic consumption of large global milk producers in 2000-2016 (million tonnes)

Źródło: opracowanie własne na podstawie FAOSTAT (2017) (www.fao.org/faostat/en/\#data) i.FAO Food... 2015, 2016, 2017.

W USA zużycie krajowe mleka zwiększało się przeciętnie w roku o 0,606 mln t, tj. o $1,52 \%$ i było mniejsze niż przyrost produkcji, której wzrost wynosił w tych latach $1,376 \mathrm{mln}$ t. Oznaczało to zwiększenie nadwyżek mleka ponad potrzeby krajowe. W Indiach wzrost produkcji mleka zagospodarowywany był przez zużycie krajowe (wzrost produkcji przeciętne w roku wynosił 5,064 mln t, a zużycia 5,065 $\mathrm{mln} \mathrm{t}$ ).

Kierunki zmian w zużyciu krajowym mleka oraz jego nadwyżkach u największych światowych producentów były zróżnicowane. Można wyróżnić dwie grupy krajów: o wzrostowej i o spadkowej tendencji zużycia krajowego mleka. Spadkowa tendencja zużycia mleka wystąpiła w takich krajach, jak Nowa Zelandia i Ukraina (rys. 4). W pozostałych badanych krajach krajowe zużycie mleka charakteryzowało się tendencją wzrostowa.

Najszybciej w latach 2000-2016 rosło zużycie mleka w Chinach, przeciętnie w roku o $2,813 \mathrm{mln} \mathrm{t}, \mathrm{tj}$. w tempie $8,7 \%$. W kraju tym roczny wzrost zużycia był o $0,918 \mathrm{mln} \mathrm{t}$ większy niż przyrost produkcji. Takie kierunki zmian oznaczały konieczność uzupełniania podaży krajowej importem.

W Brazylii, Meksyku i Pakistanie roczny wzrost zużycia tylko nieznacznie przewyższały przyrost produkcji (0,003-0,019 $\mathrm{mln} \mathrm{t}$ rocznie).

W Argentynie wzrost produkcji był o $0,047 \mathrm{mln} \mathrm{t}$ większy niż przyrost zużycia krajowego, a w Turcji o $0,035 \mathrm{mln}$ t. Takie kierunki zmian oznaczał, że kraje te powiększały swoje zdolności eksportowe mleka.

\footnotetext{
${ }^{11}$ Ten termin oznacza kraje poza UE.
} 
Wzrostem zużycia krajowego mleka charakteryzowała się także Australia. W kraju tym przy spadkowej tendencji produkcji (o 1\% rocznie) zużycie krajowe zwiększało się o $2,1 \%$. Spowodowało to zmniejszanie się eksportu mleka i jego produktów. W latach 20122016 eksport produktów mleczarskich przez Australię był niższy niż w latach 2000-2004 o $40,6 \%$.

W Rosji średni roczny spadek produkcji wynosił $0,143 \mathrm{mln} \mathrm{t,} \mathrm{tj.} \mathrm{obniżał} \mathrm{się} \mathrm{w} \mathrm{tempie}$ $0,45 \%$, natomiast zużycie krajowe zwiększało się o $0,124 \mathrm{mln}$ t., tj. w tempie 3,7\%. Było to możliwe w wyniku tendencji spadkowej w eksporcie i tendencji wzrostowej w imporcie.

W Nowej Zelandii krajowe zużycie mleka obniżyło się o 0,059 mln t, przy wzroście produkcji o $0,581 \mathrm{mln}$ t, co powodowało zwiększanie nadwyżek mleka ponad potrzeby krajowe.

Na Ukrainie zarówno produkcja mleka, jak i jego zużycie zmniejszało się. Spadek zużycia mleka był jednak niższy niż produkcji o $0,050 \mathrm{mln}$ t rocznie. Takie zmiany wynikały ze zmniejszania się eksportu i wzrostu importu.

\section{Tendencje w kształtowaniu się nadwyżek lub niedoborów mleka na rynkach krajowych}

Przedstawione zmiany w produkcji i zużyciu krajowym mleka pozwalają określić tendencje w kształtowaniu się nadwyżek lub niedoborów rynkowych mleka u największych i dużych producentów na świecie, co przedstawiono na rys. 5.

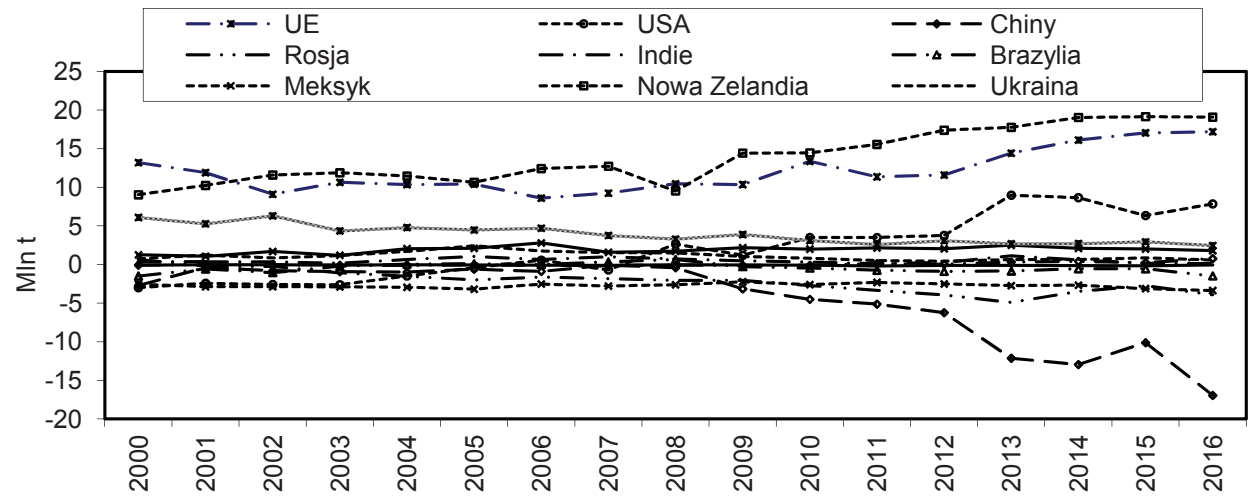

Rys. 5. Wielkość nadwyżek lub niedoborów rynkowych u największych i dużych światowych producentów mleka w latach 2000-2016 (mln t)

Fig. 5. Market surpluses or shortages of the largest and large global milk producers in 2000-2016 (million tonnes) Źródło: Obliczenia własne na podstawie FAOSTAT (2017) (www.fao.org/faostat/en/\#data) i FAO Food... 2015, 2016, 2017.

Ocena skali zmian w nadwyżkach lub niedoborach mleka w latach 2000-2016 u największych i dużych producentów mleka na świecie pozwala wyodrębnić trzy grupy państw:

- pierwszą grupę tworzą kraje, w których wzrost produkcji był większy niż wzrost zużycia krajowego. Są to kraje o rosnących nadwyżkach rynkowych mleka. Do tej grupy można zaliczyć: UE, USA, Nową Zelandię, a także Argentynę i Turcję; 
- drugą grupę tworzą kraje o rosnących niedoborach rynkowych. Do nich można zaliczyć takie kraje, jak: Chiny, Rosję, a także Meksyk, Brazylię i Pakistan;

- trzecia grupa to kraje, które charakteryzowały się tendencją spadkową w nadwyżkach rynkowych mleka. Zaliczyć można do nich: Australię, Ukrainę i Indie.

Nadwyżki rynkowe ponad potrzeby kraju w latach 2000-2016 w największej skali zwiększały się przeciętnie w roku w USA o $0,77 \mathrm{mln} \mathrm{t}$ rocznie, w Nowej Zelandii o $0,64 \mathrm{mln} \mathrm{t}$, i krajach UE o $0,363 \mathrm{mln}$ t. Z krajów tych pochodziło prawie $80 \%$ światowego eksportu mleka i jego produktów. W mniejszej skali wzrost eksportu występował w Argentynie (o 0,047 mln t) i Turcji (o 0,036 mln t). Udział tych dwóch krajów w światowym eksporcie wynosił 2,4\%.

Kraje o rosnących niedoborach rynkowych zwiększały import mleka i jego produktów w różnej skali i tempie. Chiny w latach 2000-2007 zwiększały import przeciętnie w roku o $0,074 \mathrm{mln} \mathrm{t}$, tj. w tempie $8,4 \%$. Znaczne jego przyśpieszenie wystapiło w latach 2008 2016. W tych latach import zwiększał się przeciętnie w roku o 1,806 $\mathrm{mln} \mathrm{t}$, tj. w tempie $28 \%$. W Rosji niedobory rynkowe zwiększały się przeciętnie w roku o $0,267 \mathrm{mln} \mathrm{t}$, przy obniżeniu produkcji i zwiększaniu zużycia krajowego. Bilansowanie niedoborów rynkowych odbywało się w wyniku obniżania eksportu i wzrostu importu W Meksyku, Brazylii i Pakistanie rosnące niedobory rynkowe uzupełniane były większą skalą wzrostu importu niż eksportu. Trzecia grupa państw charakteryzowała się zmniejszającymi się nadwyżkami produkcji mleka ponad potrzeby krajowe. Do tej grupy należały: Australia, Ukraina i Indie. W Australii następowało zmniejszenie produkcji, przy wzroście zużycia krajowego. Powodowało to zmniejszanie nadwyżek rynkowych mleka i jego produktów. W badanych latach nadwyżki te zmniejszały się przeciętnie w roku o $0,223 \mathrm{mln} \mathrm{t}$, tj. w tempie 5,6\%. Eksport zmniejszał się przeciętnie w roku o 0,205 mln t, a import wzrastał o 0,017 $\mathrm{mln} \mathrm{t}$.

Nadwyżki mleka ponad potrzeby Ukrainy zmniejszały się przeciętnie w roku o $0,051 \mathrm{mln}$ t. Spowodowane to było obniżaniem się przeciętnie w roku eksportu o 0,044 mln t i wzrostu importu o 0,006 mln t. Z kolei w Indiach nieznaczne zmniejszanie się nadwyżek rynkowych wynikało $\mathrm{z}$ większej skali wzrostu importu niż eksportu. Nadwyżki te zmniejszały się przeciętnie w roku o $0,006 \mathrm{mln} \mathrm{t}$.

\section{Tendencje na rynku mleka w Polsce w latach 2000-2016}

W okresie transformacji rynkowej i członkostwa Polski w UE w branży mleczarskiej dokonały się fundamentalne zmiany dostosowawcze do zmieniających się uwarunkowań zewnętrznych i wewnętrznych. Nastąpiły duże zmiany strukturalne, modernizacyjne, jak i własnościowe (Urban, 2004, Seremak-Bulge i in., 2005, Szajner, 2009). W latach 2000-2016 zmiany te były kontynuowane. W produkcji następują powolne zmiany koncentracji w gospodarstwach i regionach, co pozytywnie wpływa na towarowość produkcji (Stańko, 2013). Zmniejsza się liczba krów i producentów mleka, co przy wzrastającej wydajności krów nie powoduje spadku produkcji mleka (rys. 6). 


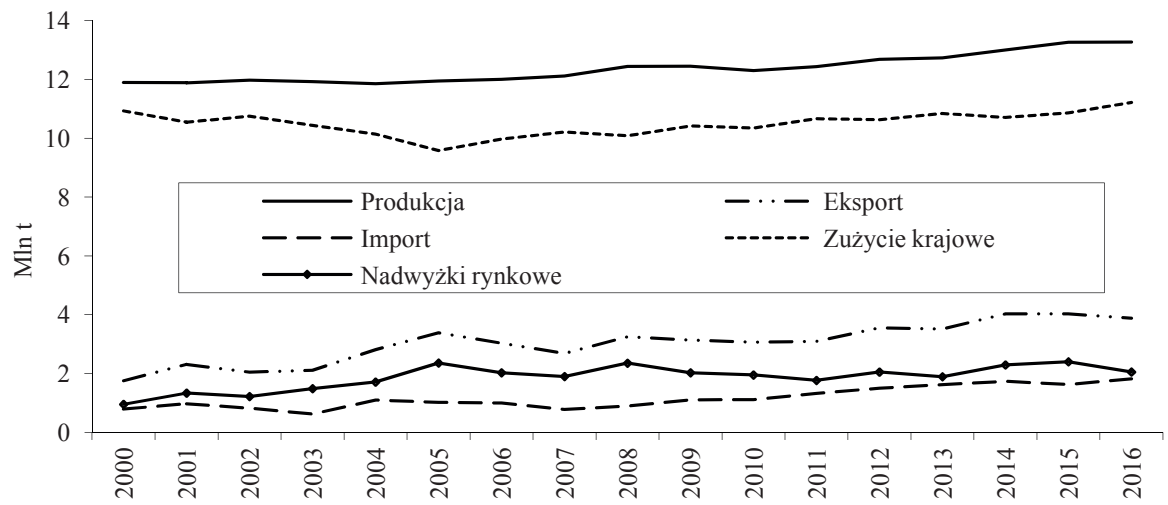

Rys. 6. Produkcja, zużycie krajowe, obroty handlowe i nadwyżki rynkowe mleka w Polsce w latach 2000-2016 $(\mathrm{mln} \mathrm{t})$

Fig. 6. Production, domestic consumption, trade turnover and market surpluses of milk in Poland in 2000-2016 (million tonnes)

Źródło: opracowanie własne na podstawie Rynek mleka. Stan i perspektywy. IERiGŻ-PIB, ARR, MRiRW numery 20-53 z lat 2000-2017 i FAOSTAT.

W latach 2000-2016 produkcja mleka w Polsce zwiększała się o 0,090 mln t rocznie, a zużycie krajowe o $0,030 \mathrm{mln}$ t. Takie tendencje w produkcji i zużyciu oznaczały, że zwiększały się nadwyżki rynkowe mleka ponad potrzeby krajowe przeciętnie w roku o 0,059 mln t. Oznaczało to roczne tempo wzrostu nadwyżek o prawie 3,7\%. Nadwyżki te były zagospodarowywane na rynkach zagranicznych poprzez wzrost eksportu przetworów mleczarskich. Eksport w tych latach zwiększał się przeciętnie w roku o 0,124 mln t mleka $^{12}$, tj. w tempie $4,3 \%$. W badanym okresie tendencją wzrostową charakteryzował się także import przetworów mleczarskich, który zwiększał się przeciętnie w roku o 0,065 mln t. Przedstawione rozważania wskazuja, że z przyrostu produkcji mleka na rynku krajowym zagospodarowywane było 33,8\%. Oznaczało to konieczność zagospodarowania na rynkach zagranicznych prawie $2 / 3$ przyrostu produkcji polskiego mleka.

\section{Podsumowanie}

$\mathrm{Na}$ świecie w produkcji dominowało mleko krowie (82-84\%) oraz bawole (12-13\%). W latach 2000-2016 wzrost produkcji mleka ogółem wyniósł $15 \mathrm{mln}$ t rocznie, w tym mleka krowiego 11,62 mln t, a bawolego 2,91 mln t.

Tendencje w produkcji mleka i jego zużyciu w badanych krajach były różnokierunkowe. W największej skali wzrost produkcji mleka ponad potrzeby krajowe zwiększał się w USA, Nowej Zelandii i krajach UE. Z tych krajów pochodziło prawie 80\% światowego eksportu mleka i jego produktów. Oznacza to dużą koncentrację w podaży produktów mleczarskich na rynkach światowych. Do krajów o rosnących niedoborach rynkowych mleka i jego produktów można zaliczyć Chiny i Rosję a także w mniejszej skali Meksyk, Brazylię i Pakistan. Od 2009 r w światowym imporcie mleka i jego produktów dominowały Chiny.

\footnotetext{
${ }^{12}$ Obroty handlu zagranicznego przetworami mleczarskimi wyrażono w ekwiwalencie mleka surowego.
} 
W Polsce w badanych latach wzrost produkcji mleka był większy niż jego zużycie, co oznaczało zwiększanie nadwyżek rynkowych ponad potrzeby krajowe. W badanych latach na rynkach zagranicznych zagospodarowano prawie $2 / 3$ przyrostu produkcji mleka w Polsce. Konieczność zagospodarowania nadwyżek rynkowych produktów mleczarskich w Polsce na rynkach zagranicznych oznacza także dużą zależność koniunktury na rynku mleka w kraju od sytuacji na rynkach światowych. Przedmiotem eksportu na rynki zagraniczne są głównie różne spożywcze produkty mleczarskie (np. masło), a także półfabrykaty (np. serwatka w proszku, kazeina, bezwodny tłuszcz mleczny) służące do produkcji innych artykułów spożywczych. Ocena tendencji w handlu zagranicznym tymi produktami wymaga oddzielnych badań.

\section{Literatura}

Eurostat (2017): Production and utilization of mill on the farm - annual data. Pobrano z: www.europa.eu/eurostat /web/agriculture/data/database).

FAO (2015): Food Outlook. BIANNUAL REPORT ON GLOBAL FOOD MARKETS, October 2015.

FAO (2016): Food Outlook. BIANNUAL REPORT ON GLOBAL FOOD MARKETS, October 2016.

FAO (2017): Food Outlook. BIANNUAL REPORT ON GLOBAL FOOD MARKETS, November 2017.

FAOSTAT (2017): Food and agriculture data (Production, Food Balance, Trade). Pobrano z: www.fao.org/ faostat/en/\#data)

Faye, B., Konuspayeva, G. (2012). The sustainability challenge to the dairy sector - The growing importance of non-cattle milk production worldwide. International Dairy Journal, 24(2), 50-56.

Guliński, P., Salamończyk, E. (2016). Światowy rynek mleka - stan obecny i perspektywy rozwoju (The global milk market - current state and prospects of development). Wiadomości Zootechniczne, 4, 118-130.

Handel zagraniczny produktami rolno-spożywczymi. Stan i perspektywy. Analizy rynkowe (Foreign trade in agrifood products. State and perspectives. Market analysis). (2001-2017), 13-44. Warszawa: IERiGŻ-PIB, ARR, MRiRW.

Integracja z Unią Europejską (Integration with the European Union), (2002). FAPA, MRiRW, Wyd. II, Warszawa. Jóźwiak, J., Podgórski, J. (1998). Statystyka od podstaw (Statistics from scratch). PWE, Warszawa.

Rolnictwo w 2003 (Agriculture in 2003) (2004). GUS Warszawa.

Rolnictwo w 2016 (Agriculture in 2016) (2017). GUS Warszawa.

Rozporządzenie Rady (WE) Nr 72/2009 z dnia 19 stycznia 2009 r. w sprawie zmian we wspólnej polityce rolnej poprzez zmianę rozporządzeń (WE) nr 247/2006, (WE) nr 320/2006, (WE) nr 1405/2006, (WE) nr 1234/2007, (WE) nr 2/2008 oraz (WE) nr 479/2008 i uchylające rozporządzenia (EWG) nr 1883/78, (EWG) nr 1254/89, (EWG) nr 2247/89, (EWG) nr 2055/93, (WE) nr 1868/94, (WE nr 2596/97, (WE) nr 1182/2005 i (WE) nr 315/2007 (Council R egulation (EC) No 72/2009 of 19 January 2009 on modifications to the Common Agricultural Policy by amending Regulations (EC) No 247/2006, (EC) No 320/2006, (EC) No 1405/2006, (EC) No 1234/2007, (EC) No 3/2008 and (EC) No 479/2008 and repealing Regulations (EEC) No 1883/78, (EEC) No 1254/89, (EEC) No 2247/89, (EEC) No 2055/93, (EC) No 1868/94, (EC) No 2596/97, (EC) No 1182/2005 and (EC) No 315/2007). Dziennik Urzędowy Unii Europejskiej, 31.1.2009 L $30 / 1$

Rynek mleka. Stan i perspektywy (Milk market. State and perspectives). (2000-2017), 20-53. Warszawa: IERiGŻ-PIB, ARR, MRiRW.

Szajner, P. (2009). Perspektywy eksportu polskich wyrobów mleczarskich w zmieniających się uwarunkowaniach (Perspectives for the export of Polish dairy products in changing conditions). Studia i Monografie, nr 146, IERiGŻ-PIB, Warszawa.

Szajner, P. (2017). Transmisja cen na rynku mleka w Polsce w latach 2004-2017 (Price transmission on milk market in Poland between 2004 and 2017). Zagadnienia Ekonomiki Rolnej, 4, 3-23.

Seremak-Bulge, J., Roman, M. (2015). Sytuacja na światowym rynku mleka i jej wpływ na polski rynek i jego możliwości rozwojowe (The situation on the global milk market and its impact on the Polish market and development opportunities). W: Sytuacja na światowych rynkach mięsa i produktów mleczarskich oraz jej wlew na rynek krajowy i możliwości jego rozwoju. Praca zbiorowa. Red. S. Stańko. Monografie programu wieloletniego, nr 31, Warszawa, s. 105-154. 
Seremak-Bulge, J., Szajner, P., Świetlik, K., Hryszko, K., Rembeza, J., Pieniażek, K. (2005). Rozwój rynku mleczarskiego i zmiany jego funkcjonowania w latach 1990-2005 (Dairy market development and changes in its functioning in the years 1990-2005). Program Wieloletni 2005-2009, nr 21, IERiGŻ-PIB, Warszawa.

Seremak-Bulge, J. (2017). Mity i fakty dotyczące spożycia mleka w Polsce (Myts and facts about milk consumption in Poland). W: Rynek mleka. Stan i perspektywy. IERiGŻ-PIB, ARR, MRiRW, nr 52, Warszawa.

Stańko, S. (2013). Zmiany i projekcje rozwoju na podstawowych rynkach rolnych w Polsce (Changes and development projections on basic agricultural markets in Poland). Wydawnictwo SGGW, Warszawa.

Timofiejuk, I. (1990). Tablice średniego tempa wzrostu według metody R (Average growth rate tables according to the R method). Zakład Badań Statystycznych GUS, Warszawa.

Urban, R. (2004). Przemiany przemysłu spożywczego w latach 1988-2003 (Transformations of the food industry in 1988-2003). Studia i Monografie, nr 121, IERiGŻ-PIB Warszawa.

Do cytowania / For citation:

Stańko S., Mikuła A. (2018). Tendencje na rynku mleka na świecie i w Polsce w latach 2000-2016. Problemy Rolnictwa Światowego, 18(1), 235-247; DOI: 10.22630/PRS.2018.18.1.22

Stańko S., Mikuła A. (2018). Tendencies in the World Milk Market and in Poland in the Years 2000-2016 (in Polish). Problems of World Agriculture, 18(1), 235-247;

DOI: $10.22630 /$ PRS.2018.18.1.22 